\title{
Common Polymorphisms in Angiogenesis
}

\author{
Michael S. Rogers and Robert J. D'Amato \\ Vascular Biology Program, Children's Hospital, and Department of Surgery, Harvard Medical School, \\ Boston, Massachusettes 02115 \\ Correspondence: michael.rogers@childrens.harvard.edu
}

A wide variety of diseases have a significant genetic component, including major causes of morbidity and mortality in the western world. Many of these diseases are also angiogenesis dependent. In humans, common polymorphisms, although more subtle in effect than rare mutations that cause Mendelian disease, are expected to have greater overall effects on human disease. Thus, common polymorphisms in angiogenesis-regulating genes may affect the response to an angiogenic stimulus and thereby affect susceptibility to or progression of such diseases. Candidate gene studies have identified several associations between angiogenesis gene polymorphisms and disease. Similarly, emerging pharmacogenomic evidence indicates that several angiogenesis-regulating polymorphisms may predict response to therapy. In contrast, genome-wide association studies have identified only a few risk alleles in obvious angiogenesis genes. As in other traits, regulatory polymorphisms appear to dominate the landscape of angiogenic responsiveness. Rodent assays, including the mouse corneal micropocket assay, tumor models, and a macular degeneration model have allowed the identification and comparison of loci that directly affect the trait. Complementarity between human and animal approaches will allow increased understanding of the genetic basis for angiogenesis-dependent disease.

\begin{abstract}
$A$ ngiogenesis is the process by which new Ablood vessels are formed from existing vessels. Angiogenesis is regulated by a wide variety of endogenous molecules, most of which have additional functions. It is often implicitly assumed that a given angiogenic stimulus (hypoxia, VEGF gradient, etc.) will produce the same response. However, such an assumption ignores the possibility of quantitative and even qualitative differences in angiogenic response resulting from genetic variation. Angiogenesis-regulating genetic variation affects the ability of an organism to respond to angiogenic stimuli. Thus, it may
\end{abstract}

affect susceptibility to, or the progression of, angiogenesis-dependent disease.

\section{IDENTIFYING ANGIOGENESIS- REGULATING GENETIC VARIATION}

Genetic variations that alter angiogenic responsiveness can be detected by a variety of methods. In animals, there are several models of angiogenesis in which variation has been observed, and in many cases strain-related differences among these models are correlated. The best studied of these is the corneal micropocket assay where the amount of growth factor required to

Editors: Michael Klagsbrun and Patricia D’Amore

Additional Perspectives on Angiogenesis available at www.perspectivesinmedicine.org

Copyright (C) 2012 Cold Spring Harbor Laboratory Press; all rights reserved; doi: 10.1101/cshperspect.a006510

Cite this article as Cold Spring Harb Perspect Med 2012;2:a006510 
M.S. Rogers and R.J. D'Amato

elicit a given response can vary by more than 10 -fold between different strains of mice.

In the case of humans, assays have not been identified that can measure angiogenic responsiveness. Nevertheless, there are a number of mechanisms by which angiogenesis response alleles might be identified. There are several Mendelian diseases that result in telangiectasia and other vascular abnormalities. However, such traits often reduce reproductive fitness, are thus not common in the population, and as a result contribute little to overall human disease. However, they can provide leads for candidate genes for other studies. In candidate gene studies, polymorphisms in genes previously identified as being involved in angiogenesis are tested for their association with the trait in question. Importantly, because it begins with candidate genes, this method does not allow novel genes or pathways involved in angiogenesis to be discovered. In contrast, advances in genetics have allowed performance of genomewide association studies (GWASs). Currently, these studies are performed by testing tag single nucleotide polymorphisms (SNPs) for their association with a phenotype in question. Generally, such studies require very large sample sizes to overcome statistical problems with multiple testing and imperfect linkage disequilibrium implicit in the tag SNP approach. As a result, detailed phenotyping and subgroup analysis are not typically available in GWASs; however, this method allows the identification of novel genes associated with a particular trait in the general population.

\section{CANDIDATE GENE STUDIES IN HUMANS}

For the reasons outlined above, the vast majority of angiogenesis genetic studies in humans have taken a candidate gene approach; that is, they have focused on asking whether polymorphisms in genes associated with angiogenesis can affect angiogenesis-dependent disease. However, the converse has not been done; that is, the question of which polymorphisms most strongly affect angiogenesis has not been asked. Thus, it is possible that the common human polymorphisms that most strongly affect angiogenesis have not been identified. As a result, the overall effect of genetic polymorphism on angiogenesis-dependent disease has not yet been rigorously tested. Nevertheless, polymorphisms in several angiogenesis-related genes have been shown to affect disease susceptibility and/or progression. For these genes we outline (1) the role of a given gene in angiogenesis, (2) the nature of observed common polymorphisms in that gene and any functional consequences known, (3) the association of polymorphisms with known angiogenesisdependent diseases, and (4) whether the observed correlation seems likely to be mediated by changes in the angiogenic response. In the majority of cases, polymorphisms associated with differences in angiogenic response are regulatory in nature. This is consistent with the observation in expression quantitative trait locus (eQTL) studies that regulatory polymorphisms dominate the variation landscape (Schadt et al. 2003; Stranger et al. 2007; Cahan et al. 2009).

These polymorphisms have occasionally been associated with conditions that are not typically believed to be angiogenesis related. For example, a polymorphism in the VEGF gene has been associated with kidney function in chronic kidney disease. Although this may indicate that angiogenesis has an as-yet underappreciated role in kidney disease, it is possible that the regulation of kidney development and podocyte function provided by VEGF is the mechanism by which this polymorphism affects kidney disease (Kottgen et al. 2010). We will typically not highlight such a role because the gene in question often has other nonangiogenesis-related functions. Similarly, we will not highlight cases where association studies have failed, because such failures are often a result of power issues.

In candidate gene studies, polymorphisms in VEGF, VEGFR2, eNOS, HIF-1 $\alpha$, MMP2, TIMP3, IL-8, CXCR2, and $\alpha$ v and $\beta 3$ integrins are clearly angiogenesis-dependent disease associated and upon further study those in PAR-1, galectin-3, and adrenomedullin are likely to be connected. Less certain are associations with polymorphisms in BDNF, thrombospondin, 
angiopoietins, and TIE2, whereas associations with endostatin and erythropoietin polymorphisms are unlikely to be biologically relevant. In the cases of polymorphisms in VEGFR1, IL-6, IL-10, TNF- $\alpha$, other MMPs, TIMPs, clotting cascade proteases, and BMP-9 pathway members there appear to be associations with disease; however, it is unclear whether these are angiogenesis mediated or not.

\section{VEGF}

Vascular endothelial growth factor (VEGF) was originally described as vascular permeability factor and is a relatively specific endothelial cell mitogen and chemotactic factor that is important in a wide variety of angiogenic processes. In addition, it is also involved in kidney and lung function as well as serving as a survival factor for neuronal cells. The gene is critical to life; thus, even the haploid state results in embryonic lethality in mice. Nevertheless, the triploid state appears to be compatible with life in humans (Mandal et al. 2007).

The VEGF gene is highly polymorphic, with hundreds of polymorphisms currently annotated in dbSNP (Fig. 1). Of these there are dozens with a minor allele frequency $>1 \%$. These are organized into three major regions of linkage disequilibrium, one well upstream of the transcription start point, one encompassing the promoter and the first six exons, and a third covering the last two exons, including the $3^{\prime}$ UTR (Garcia-Closas et al. 2007). Little is known about the first block; however, one study implicates a polymorphism in this region in bladder cancer susceptibility (Garcia-Closas et al. 2007). The third ( $3^{\prime}$ UTR) region contains one well-studied

$\begin{array}{rrrrrrr}-15000 & -10000 & -5000 & 0 & 5000 & 10000 & 15000 \quad 20000\end{array}$

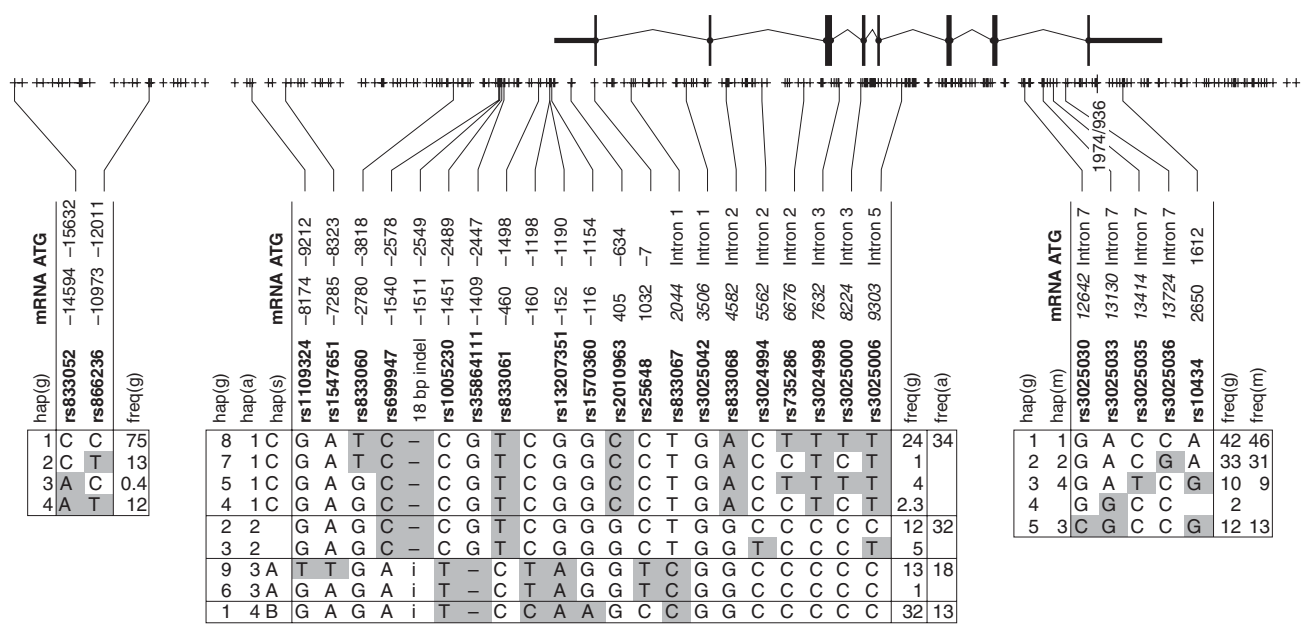

Figure 1. VEGF gene polymorphisms. The VEGF gene and surrounding sequence are outlined. Each + represents a polymorphic site. The position of the full-length transcript, exons, and longest splice form are diagrammed. The position of commonly assessed polymorphisms according to both of the commonly used numbering schemes (from the transcription start point "mRNA," and from the translation start point "ATG") are indicated. The three major regions of linkage disequilibrium are shown, together with common haplotypes. The haplotype numbering schemes of Stevens (s) (Stevens et al. 2003), Awata (a) (Awata et al. 2005), Garcia-Closas (g) (Garcia-Closas et al. 2007), and McKay (m) (McKay et al. 2009) are indicated, as well as the frequency of the haplotypes in the indicated control populations. Shaded genotypes indicate a difference with the chimpanzee or orangutan genome, suggesting that the shaded allele is the derived allele. The position of the $936 \mathrm{C}>$ T polymorphism in the $3^{\prime}$ UTR is also indicated. 
polymorphism, 936C $>\mathrm{T}$ (rs3025039). In carriers of the 936 Tallele (heterozygous or homozygous) in the $3^{\prime}$ UTR, the VEGF plasma level is, on average, one-third that of noncarriers (Renner et al. 2000).

As outlined in Figure 1, the second region of linkage disequilibrium, which contains the VEGF gene promoter, is complex. It has at least four major common haplotypes, as well as several minor haplotypes, resulting in more than 10 common promoter genotypes in humans. There have been several studies that have assessed the effect of differing haplotypes on promoter activity. However, the effect of polymorphisms on gene promoter activity and RNA levels seems to be cell-type and stimulus specific. Nevertheless, circulating VEGF levels are highly heritable (Pantsulaia et al. 2004) and correlations have been found between genotype in both the second and third regions of LD and VEGF levels in multiple tissues and fluids, as well as with microvessel density, although there are conflicting reports as well. For example, multiple studies have found no correlation between cancer patient serum VEGF and VEGF gene polymorphisms. This is unsurprising because any genetic signal is likely to be lost in tumor-induced variability. Also, for a tumor to grow it must have first produced sufficient angiogenic factor to induce angiogenesis, and this requirement does not change with VEGF genotype. In the case of normal controls, conflicting reports about the effect of a given polymorphism or haplotype are likely because the effect of genotype on VEGF expression is cell-type and stimulus specific. This situation is further complicated by the fact that individual polymorphisms are often studied in isolation, but are not inherited in isolation. Rather, they are inherited as part of a larger haplotype, and thus individuals grouped according to genotype at a single polymorphism are actually mixtures of individuals who bear different haplotypes of the VEGF promoter.

There are currently more than 350 studies examining the association between VEGF genotype and human disease (Table 1). However, many of these studies are difficult to interpret because they examine only individual SNP genotypes, rather than looking at haplotypes. As a result, it is possible that many studies may fail to see an association as a result of dilution of affected with unaffected individuals. For example, in early studies, the $\mathrm{C}$ allele of the $405 \mathrm{G}>\mathrm{C}$ polymorphism, which is contained in haplotype 1, was associated with endometriosis susceptibility. In contrast, the Tallele of the $-460 \mathrm{~T}>\mathrm{C}$ polymorphism, which is contained in both haplotypes 1 and 2, fails to show significant association despite a promising trend (Bhanoori et al. 2005). This is likely because of a dilution of the "active" haplotype 1 with haplotype 2 , and later studies have amply confirmed the importance of VEGF promoter polymorphisms in endometriosis.

To discriminate the major genotypes in the VEGF promoter, it is necessary to genotype at least three polymorphisms (e.g., - 1540/ $-2578 / \mathrm{rs} 699947,-116 /-1154 / \mathrm{rs} 1570360$, and $405 /-634 / \mathrm{rs} 2010963)$. In addition, the +936 (rs3025039) polymorphism in the $3^{\prime}$ UTR should be tested. In general, current tag SNP approaches seem to be less powerful in detecting association, as such approaches fail when assessment of "functional" SNPs succeeds. For example, from studies on traditional SNPs there is substantial although not uniform evidence that VEGF polymorphisms play a small role in susceptibility to macular degeneration (Galan et al. 2010) and a somewhat stronger role in progression to the wet form of the disease (Francis et al. 2009). However, neither of the studies taking a tag SNP approach (Hanaoka et al. 2009; Zablotna et al. 2010) have noted the association.

In addition to macular degeneration, VEGF gene polymorphisms have been associated with a wide variety of diseases and other phenotypes (Table 1). Unsurprisingly, haplotype 3 has even been associated with an increase in overall lifespan in an Italian population (Del Bo et al. 2008). As might be expected, VEGF polymorphisms are associated with a wide variety of cancer-related phenotypes, including overall incidence of cancer, as well as thrombotic complications in some, but not all cancer types. Importantly, VEGF may have different (or no) effects at different times in disease progression. For example, in the case of cancer, VEGF may 
Table 1. Phenotypes in which VEGF polymorphisms have been studied

\begin{tabular}{|c|c|}
\hline Life span & Psoriatic arthritis \\
\hline Cancer thrombosis & Renal graft survival \\
\hline Glioma/glioblastoma & Heart transplant acute rejection \\
\hline Head and neck cancer & Acute respiratory distress syndrome \\
\hline Nasopharyngeal carcinoma & $(-)$ Type 2 diabetes \\
\hline Thyroid carcinoma & Type 1 diabetes \\
\hline Oral cancer & Diabetic neuropathy \\
\hline Laryngeal squamous cell carcinoma & Diabetic nephropathy \\
\hline Esophageal cancer & Diabetic retinopathy \\
\hline Esophagogastric junction cancer & Retinopathy of prematurity \\
\hline Gastric cancer & Age-related macular degeneration \\
\hline Colorectal cancer & Ptergium \\
\hline Hepatocellular carcinoma & Ocular pseudoxanthoma elasticum \\
\hline Gallbladder cancer & $\mathrm{VO}_{2} \max$ \\
\hline Pancreatic cancer & Asthma \\
\hline Lung cancer & $(-)$ Smoking COPD \\
\hline Renal cancer & Depression \\
\hline Breast cancer & Migraine \\
\hline Transplant-related Kaposi’s sarcoma & Alzheimer's disease \\
\hline$(-)$ Melanoma & $(-)$ Stroke \\
\hline Leukemia/lymphoma & (-)Parkinson's disease \\
\hline$(-)$ Prostate cancer & Brain arteriovenous malformation \\
\hline Bladder cancer & Amyotrophic lateral sclerosis \\
\hline Ovarian cancer & Frontotemporal lobe degeneration \\
\hline Cervical cancer & Vascular dementia \\
\hline Endometrial cancer & Hippocampus morphology \\
\hline Leiomyoma & Childhood urinary tract infection vesicoureteral \\
\hline Sarcoidosis & reflux, renal scarring \\
\hline Polycystic ovary syndrome & Henoch-Schonlein purpura nephritis \\
\hline Endometriosis & Hypertensive nephropathy \\
\hline Adenomyosis & Type 2 diabetes chronic renal insufficiency \\
\hline In vitro fertilization implantation & End stage renal disease \\
\hline Recurrent pregnancy loss & Progression of IgA nephropathy \\
\hline Preterm delivery & Progression to chronic kidney disease stage 5 \\
\hline$(-)$ Ectopic pregnancy & Primary glomerulonephritis \\
\hline (-)Preeclampsia & Calcium oxylate stone disease \\
\hline HELLP & Gastroduodenal ulcer \\
\hline Low birth weight, necrotizing enterocolitis & Bisphosponate-induced osteonecrosis of the jaws \\
\hline Sudden infant death syndrome & Osteonecrosis of the femoral head \\
\hline Heart defects & Osteoporosis \\
\hline Coronary artery disease & Biliary atresia \\
\hline Chronic heart failure prognosis & Occupational benzene hematotoxicity \\
\hline Giant cell arteritis & (-)High-altitude pulmonary edema \\
\hline Kawasaki disease & Bronchopulmonary dysplasia \\
\hline (-)Behcet's disease & Encapsulating peritoneal sclerosis in \\
\hline$(-)$ Systemic sclerosis & Progressive increase in peritoneal transport, \\
\hline Arthritis & mortality \\
\hline Ankylosing spondylitis & $(-)$ Baseline peritoneal permeability \\
\hline Atopy & Hydrocele in lymphatic filariasis \\
\hline Lupus & PM2.5-induced heart rate variability \\
\hline Psoriasis & (-)Steroid-sensitive nephrotic syndrome \\
\hline
\end{tabular}


M.S. Rogers and R.J. D'Amato

Table 1. Continued

$(-)$ Chronic pancreatitis

(-) Circulating HHV-8 DNA

$(-)$ Hot flashes

(-)Progressive massive fibrosis (coal miners)

$(-)$ Hemifacial spasm

(-)Autosomal-dominant polycystic kidney disease

progression

Boldface text indicates that the bulk of evidence confirms an association between one or more VEGF polymorphisms and the risk, severity, progression (including metastasis), age of onset, or outcome for the indicated trait. A $(-)$ indicates that the bulk of evidence shows no association of the trait with the VEGF polymorphism(s) studied. Italic text indicates conflicting evidence. For other listed traits, only a single report is available and, thus, the association should be considered unconfirmed. References available from the authors upon request.

play a minor role in tumor initiation, but a significant role in progression or metastasis. Melanoma is a rare example of a cancer in which the pre-angiogenic lesion is readily detected and is thus instructive. VEGF polymorphisms have not been associated with risk of disease; however, a low-expressing VEGF haplotype is associated with thin (i.e., nonangiogenic) melanoma (Howell et al. 2002). This observation is consistent with the notion that angiogenesis polymorphisms play a less important role in tumor initiation than in tumor progression and metastasis.

In addition, gene-gene interactions can affect whether a particular polymorphism affects cancer risk. For example, several metaanalyses have shown that the risk of developing breast cancer is not associated with genotype in the $+936 \mathrm{C}>\mathrm{T}$ polymorphism in the general population. However, in BRCA1 carriers the low-VEGF T-allele confers protection from disease (Jakubowska et al. 2008). Similarly, although large case-control studies have failed to find an association between prostate cancer risk and VEGF polymorphisms (Jacobs et al. 2008), when gene-gene interactions are considered, several smaller studies have shown that VEGF polymorphisms can play a role in disease risk or aggressiveness (Sfar et al. 2010; VanCleave et al. 2010).

Association between a disease and VEGF polymorphisms does not necessarily mean that the disease is angiogenesis dependent. For example, hydrocele development in lymphatic
(-)Inflammatory bowel disease

(-)Familial Mediterranean fever

(-)Tropical spastic paraparesis in HTLV1-infected individuals filariasis patients is strongly affected by genotype at the -460 polymorphism. However, because this condition is characterized by extensive vascular leak, it is likely that the effect is mediated by induction of vascular permeability by VEGF, rather than by angiogenesis. Another example arose from the observation that mice with a deletion of the hypoxia response element in the VEGF promoter develop adult-onset motor neuron degeneration reminiscent of amyotrophic lateral sclerosis (ALS) (Oosthuyse et al. 2001). This clue led to the discovery that VEGF is a survival factor for neural cells. Thus, the observation that the 22578AA genotype is associated with ALS in men does not necessarily indicate that angiogenesis is involved in ALS; rather, it suggests that VEGF protects neurons from the insults that lead to neuronal degeneration in the disease. Similarly, development of type 1 diabetes has been associated with particular genotypes in the VEGF gene (Del Bo et al. 2006). However, long distance linkage has been demonstrated between the VEGF gene and the adjacent HLA complex (Chen et al. 2009). Given the very strong association between HLA genotype and type 1 diabetes, it is possible that the VEGF association results from linkage disequilibrium with the HLA complex, rather than from differences in VEGF regulation.

Pharmacogenomic studies on angiogenesis inhibitors are currently somewhat rare. However, one group has identified an association between VEGF promoter polymorphisms and 
breast cancer response to bevicuzimab, with genotypes consistent with haplotype 4 associated with dramatic extension of overall survival (Schneider et al. 2008). In addition, genotypes consistent with haplotype 1 reduced the incidence of treatment-associated hypertension (Schneider et al. 2008), an observation that has since been confirmed (Etienne-Grimaldi et al. 2010), and extended to sunitinib-treated metastatic renal cancer patients (Kim et al. 2009b). In colorectal cancer, VEGF promoter polymorphisms predict response and time to progression with anti-VEGF therapy (Pander et al. 2010). However, promoter polymorphisms have similar predictive power with chemotherapy regimens lacking an anti-VEGF component (Chen et al. 2010a). Similar results are obtained in lung cancer (Heist et al. 2008). This suggests either that current cytotoxic chemotherapeutic regimens have a significant antiangiogenic component even in the absence of a targeted angiogenesis inhibitor, or that growth in an environment with altered VEGF availability affects the biological characteristics of a tumor in a way that alters its response to chemotherapy.

\section{VEGFR2}

VEGFR2 is a tyrosine kinase receptor containing several nonsynonymous SNPs of unknown functional significance, and several regulatory SNPs. For example, the $-604 \mathrm{C}$ allele decreases transcriptional activity and protects against age-related macular degeneration (Galan et al. 2010). In addition, there is evidence of genegene interactions with VEGF genotype (VanCleave et al. 2010). However, studies to identify VEGFR2 polymorphisms that might predict Lucentis response were negative (KloeckenerGruissem et al. 2011).

In contrast, in colon cancer, the -604CC promoter genotype is associated with increased microvessel density and decreased survival, whereas the translationally silent $1192 \mathrm{C}>\mathrm{T}$ polymorphism is associated with decreased microvessel density and increased survival (Hansen et al. 2010). A tag SNP approach has generated some evidence for association between glioblastoma and VEGFR2 genotype (Andersson et al. 2010). However, breast and lung cancer studies are uniformly negative. In a small study of prostate cancer, H472Q affects the frequency of sorafanib-induced side effects, which are in turn predictive of patient survival (Jain et al. 2010). Similarly, in CML the H472Q polymorphism has been shown to affect the likelihood of complete cytogenetic response to imatinib therapy as well as the odds of treatment failure (Kim et al. 2010).

The $472 \mathrm{Q}$ variant is overrepresented in endurance athletes, where it is also associated with an increase in $\mathrm{VO}_{2}$ max and with muscle fiber type (Ahmetov et al. 2009). Variation in this polymorphism is also associated with recurrent pregnancy loss (Su et al. 2011). Finally, as is true of VEGF, osteonecrosis of the femoral head has been associated with VEGFR2 genotype (Hong et al. 2010) likely as a result of the importance of angiogenesis to bone repair.

VEGFR2 genotype is associated with several additional diseases; however, whether the mechanism involved is angiogenesis related is uncertain. For example, the V297I variant is associated with atopy (Park et al. 2006), especially in combination with TNF genotype (Park et al. 2007) as well as with hemorrhagic stroke (Zhang et al. 2009). VEGFR2 SNPs are also associated with sarcoidosis (Pabst et al. 2010), coronary artery disease in both normal individuals (Wang et al. 2007) and in Kawasaki disease patients (Kariyazono et al. 2004), and saphenous vein graft patency (Ellis et al. 2007), underlining the importance of the VEGFR2 gene in atherosclerosis.

HIF- $1 \alpha$

HIF- $1 \alpha$ is a transcription factor that is involved with major cellular oxygen sensing pathways. In hypoxia, the protein is stabilized and upregulates genes involved in erythropoiesis and angiogenesis such as erythropoietin, adrenomedullin, and VEGF. The oxygen sensitivity of this response can vary widely between individuals (Brooks et al. 2009) and two polymorphisms in the gene appear to affect function 
M.S. Rogers and R.J. D'Amato

(P582S rs11549465 $+1772 \mathrm{C}>\mathrm{T}$ and A588T rs11549467 + 1790G > A) by increasing protein levels and transcriptional activity (Tanimoto et al. 2003). The functional nature of these alleles is underlined by repeated reports that they are overrepresented in high-performance athletes and their association with maximal exerciseinduced oxygen consumption.

Interestingly, although there are only a few positive reports of association between HIF$1 \alpha$ polymorphisms and cancer incidence, there are repeated reports in multiple tumor types of association with tumor size and disease aggressiveness (Zhao et al. 2009). Interestingly, the A588T polymorphism is associated with gastric cancer in Tibetans ( $\mathrm{Li}$ et al. 2009a). Importantly, this group shows a high frequency of alleles that alter HIF-1 $\alpha$ regulation and are believed to contribute to high-altitude adaptation (Simonson et al. 2010). Thus, this association may only have relevance to this population.

The P582S polymorphism is associated with an increase in coronary collateral arteries (Resar et al. 2005) and thus cardiovascular disease patients with this genotype tend to present with stable angina rather than acute myocardial infarction (Hlatky et al. 2007). In contrast, in hemodialysis patients, polymorphisms are associated with acute myocardial infarction and hypotension (Zheng et al. 2009). It is also associated with susceptibility to systemic sclerosis, a disease characterized by vascular inflammation and angiopathy (Wipff et al. 2009). Finally, distinct polymorphisms of unknown significance are associated with osteonecrosis of the femoral head (Hong et al. 2007).

\section{Nitric Oxide Synthase (NOS3/eNOS)}

Nitric oxide is a multipotent signaling molecule with significant effects on angiogenesis, vasodilation, vascular permeability, and inflammation. In addition, as a free radical it has significant mutagenic potential. Endothelial nitric oxide synthase (eNOS/NOS3) is the major endothelial producer of nitric oxide. Three polymorphisms in NOS3 have been well studied: $-786 \mathrm{~T}>\mathrm{C}$ in the promoter, a variable number tandem repeat in the fourth intron, and $894 \mathrm{G}>\mathrm{T}$ in exon 7 which results in an amino acid change (E298D) in the protein. All of these polymorphisms can affect eNOS activity (Wang et al. 2000; Marangoni et al. 2008). Although the polymorphisms were initially identified in the context of cardiovascular disease, they have also been associated with several angiogenesis-dependent diseases. Because the E298D polymorphism has been associated with differences in collateral formation (Lamblin et al. 2005), angiogenesis may be the mechanism by which this polymorphism affects a subset of cardiovascular disease.

Retinopathy of prematurity is associated with all three polymorphisms (Rusai et al. 2008; Yanamandra et al. 2010), whereas the coding polymorphism affects endometriosis (Kim et al. 2009a), and the promoter polymorphism affects idiopathic osteonecrosis of the femoral head (Glueck et al. 2007).

In cancers such as non-small cell lung cancer (Fujita et al. 2010), acute lymphoblastic leukemia (ALL), and breast cancer there is evidence to suggest that NOS3 mutations can affect disease susceptibility (Haas et al. 2009; Hao et al. 2010; Zintzaras et al. 2010). Such susceptibility might be a result of increased angiogenic activity and a consequently decreased threshold for the angiogenic switch. In addition, increased free-radical production might increase the mutation rate in a tissue, thereby increasing the rate of cancer formation. This possibility is highlighted by reports of an interaction between NOS3 genotype and antioxidant consumption in the risk of breast (Li et al. 2009b) and prostate (Lee et al. 2009a) cancers. In contrast, progression to advanced disease and metastasis are necessarily angiogenesis dependent. Thus, it is interesting to observe that in several cancers the genotype is not significantly different between controls and patients; however, if one focuses on early progression, metastasis, and/ or disease-free survival following treatment there is a correlation with genotype.

Finally, there is also evidence that NOS3 polymorphisms can influence response to and side effects from cancer therapy. In ALL the amino acid polymorphism can affect a patient's IQ following cranial radiation (Krajinovic et al. 
2005). Similarly, in the breast cancer setting, a reduced incidence of radiation-induced telangiectasias was noted in women with lower-activity NOS3 genotypes (Kuptsova et al. 2008). In NSCLC a decreased risk of pneumonitis was noted in carriers of the low-activity E298D allele (Hildebrandt et al. 2010); however, that effect is almost certainly not attributable to differences in angiogenesis, but rather to inflammatory differences. Similarly the decreased rectal cancer survival observed in carriers of the E298D allele following radiotherapy (Funke et al. 2009) are likely a result of decreased low reactive oxygen production rather than any angiogenic effects.

\section{Integrins}

Several integrins are expressed on endothelial cells, including $\alpha v \beta 3$, which is upregulated in the angiogenic endothelium. During angiogenesis, this complex interacts directly with VEGFR2 and PDGFR $\beta$ and cooperates with VEGFR2 to stimulate endothelial cell migration. An early study showed that the $\beta 3$ integrin L33P polymorphism increased the risk of melanoma as well as ovarian and breast cancers (Bojesen et al. 2003). In the case of breast cancer, this risk appears to be particularly strong for younger women (Wang-Gohrke and ChangClaude 2004) and extends to the risk of metastasis (Ayala et al. 2003; Langsenlehner et al. 2006). Polymorphisms in $\alpha \mathrm{v}$ integrin have been implicated in susceptibility to hepatitis B virus induced hepatocellular carcinoma (Lee et al. 2009b) and regional spread in gastric cancer (Scartozzi et al. 2010). Other integrins (e.g., $\alpha v \beta 5, \alpha 5 \beta 1)$ are also expressed on endothelial cell and involved in angiogenesis, but studies have not identified polymorphisms in these genes that regulate angiogenesis or angiogenesis-dependent disease.

\section{IL-8/CXCR2}

IL-8 is a VEGF-independent stimulator of angiogenesis which acts through the receptors CXCR1 and CXCR2, with the latter being the endothelial receptor ( $\mathrm{Li}$ et al. 2003). The Il-8 $-251 \mathrm{~T}>\mathrm{A}$ polymorphism leads to increased
IL-8 production (Hull et al. 2000) and increases plasma IL-8 levels (Lee et al. 2005).

There have now been over 50 studies conducted to assess the relationship between the IL-8 - 251A allele and cancer. A meta-analysis of these studies found that the A allele increases the risk of nasopharyngeal carcinoma and that it increased the risk of a group of "other" less studied cancers (Gao et al. 2010). Importantly, when studies with population-based controls were compared with those with hospital-based controls it was found that hospital-based controls indicated an increased risk of cancer, whereas population-based controls indicated a decreased risk of cancer from the A allele (Gao et al. 2010). This result suggests that overall health status may be affected by an individual's IL-8 allele and, thus, the immune functions of IL-8 may confound the ability to detect differences in cancer resulting from angiogenic differences. In this context, the effect of the A allele on tumor recurrence may be instructive. In stage III colon cancer recurrence is predicted by the high expressing A allele (Lurje et al. 2008), as is recurrence in rectal cancer (Gordon et al. 2006). This allele also predicts incidence, recurrence, and overall survival in gastric adenocarcinoma (Lurje et al. 2010a) and increased risk of and aggressiveness in breast cancer (Snoussi et al. 2010). Interestingly, this polymorphism also represents a pharmacogenomic marker in antiangiogenic therapy. It is associated with lower response to bevicuzimab and metronomic cyclophosphamide in ovarian cancer as is the CXCR2 $+785 \mathrm{C}>$ T polymorphism (Schultheis et al. 2008). At the distinct CXCR2 $+1208 \mathrm{C}>\mathrm{T}$ polymorphism, the TT genotype is associated with both incidence and aggressiveness in breast cancer (Snoussi et al. 2010).

\section{Proteases and Protease Inhibitors}

Several proteases, including matrix metalloproteinases (MMPs), their tissue inhibitors (TIMPs), and members of the plasminogen system, are known to be involved in the invasion and remodeling required for angiogenic vessel outgrowth. In addition to remodeling matrix, some proteases and inhibitors have more direct 
M.S. Rogers and R.J. D'Amato

activities. For example, the plasminogen fragment angiostatin has antiangiogenic activity (O'Reilly et al. 1994). Similarly TIMP-3 antagonizes VEGF binding to VEGFR2 (Qi et al. 2003) and inhibits endothelial chemotaxis, collagen gel invasion, and vessel growth in the CAM assay (Anand-Apte et al. 1997). Certain lossof-function mutations in TIMP-3 result in Sorsby's fundus dystrophy, decreasing the antiangiogenic properties of Bruch's membrane and increasing susceptibility to choroidal neovascularization (Weber et al. 1994). Similarly, susceptibility to age-related macular degeneration is affected by polymorphisms in the TIMP3 gene (Chen et al. 2010b). Longer length in an MMP9 promoter microsatellite is also associated with susceptibility to wet ARMD (Fiotti et al. 2005). In men with proliferative diabetic retinopathy the MMP2 - 1306C allele is associated with higher plasma MMP2 levels and with disease (Beranek et al. 2008) and the similar $-735 \mathrm{C}>\mathrm{T}$ polymorphism is associated with psoriasis (Vasku et al. 2002). In these diseases, it seems likely that gene polymorphism modulates disease susceptibility by modulating the angiogenic response, although other mechanisms are possible. Polymorphisms in several of these genes are also associated with cancer; however, in all of these cases, because substantial tissue remodeling is a hallmark of neoplastic disease it is difficult to determine whether disease susceptibility is mediated by increased angiogenesis, increased tissue remodeling, or both.

\section{Promising Candidates}

Adrenomedullin is a potent vasodilator and a pro-angiogenic factor (Martinez 2006). An in/ del in the $3^{\prime}$ UTR of the adrenomedullin gene is associated with progression-free survival in bevicuzimab- and cyclophosphamide-treated ovarian cancer (Schultheis et al. 2008). Interestingly, this polymorphism is also associated with hypertension (Ishimitsu et al. 2001), a common side effect of anti-VEGF therapy.

Full-length galectin-3 is involved in a number of processes important to tumorgenesis including anchorage independent growth and tumor cell proliferation. The protein is also cleaved by MMPs and the cleaved form is involved in chemotaxis and angiogenesis. A $\mathrm{P} 64 \mathrm{H}$ polymorphism adjacent to one of the MMP cleavage sites (between A62 and Y63) affects cleavage efficiency and angiogenesis stimulatory activity (Nangia-Makker et al. 2010). The $H$ allele, which results in greater angiogenesis, is more common in Caucasian women than in Asian woman and has been hypothesized to explain a portion of the increased risk of breast cancer in Caucasian women (Balan et al. 2008). The $\mathrm{H}$ allele also increases the risk of breast cancer in each population independently (Balan et al. 2008).

Proteinase-activated receptor 1 (PAR-1) has been shown to regulate the differential release of pro- and anti-angiogenic factors from platelets (Ma et al. 2005; Italiano et al. 2008). A promoter in/del at position -506 in the gene is associated with outcome in gastric cancer patients (Lurje et al. 2010a) and with tumor recurrence in esophageal carcinoma (Lurje et al. 2010b).

\section{GENOME-WIDE ASSOCIATION STUDIES IN HUMANS}

In principle, genome-wide association studies for polymorphisms affecting conditions such as cancer or cardiovascular disease might discover angiogenesis response alleles. There are at least two potential examples of this. First, there have been repeated reports of genomewide association between cancer and SNPs near the fibroblast growth factor receptor 2 gene (FGFR2) (Easton et al. 2007; Hunter et al. 2007; Thomas et al. 2009; Gaudet et al. 2010; Turnbull et al. 2010; Li et al. 2011), with the risk allele increasing the expression of the gene (Meyer et al. 2008). Overlap between array $\mathrm{CGH}$-determined $\mathrm{CNV}$ suggests that several bFGF QTLs may be regulated by copy-number variation alleles (Cho et al. 2006). This protein is the receptor for several fibroblast growth factors, including FGF2, a powerful angiogenesis stimulator (Shing et al. 1984; Klagsbrun and Shing 1985). A similar case is that of the phospholipase PLCE1, an intracellular regulator of 
growth factor signaling in both endothelial and other cell types, including cancer cells. An amino acid substitution in this gene is associated with esophageal squamous cell carcinoma in Chinese subjects (Wang et al. 2010a). The relevance of both of these findings to angiogenesis is questionable because both proteins are also mitogens and can confer survival signals. Nevertheless, it is interesting that polymorphisms in these genes, rather than others with similar characteristics, are observed to increase the risk of cancer. Thus, one might hypothesize that both the mitogenic and angiogenic activities of these proteins are involved in conferring susceptibility to cancer. Indeed, it is possible that some of the genes and regions currently identified as cancer risk alleles have as-yet undiscovered roles in angiogenesis.

A simpler case involves the HTRA1 gene in age-related macular degeneration (ARMD). HTRA1 is a serine protease expressed in the retinal pigment epithelium. It has been shown to selectively cleave eight RPE proteins. These include several ECM proteins that might regulate angiogenesis, such as fibromodulin, clusterin, ADAM9, and vitronectin (An et al. 2010). Promoter polymorphisms in HTRA1 have been associated specifically with wet ARMD (Dewan et al. 2006) suggesting that increased expression of this gene results in increased susceptibility to angiogenesis in the retina. However, the polymorphisms involved are part of a haplotype that also results in loss of function in the ARMS2 (LOC387715) gene, and this loss appears also to be required for ARMD susceptibility (Yang et al. 2010).

The absence of obvious angiogenesisrelated gene associations in GWASs of diseases that are clearly angiogenesis dependent might be explained in a number of ways. First, there remains a substantial amount of "dark matter" in genetics. That is, loci identified by current GWASs and family studies explain only a small fraction of observed heritability (Manolio et al. 2009). It may be that angiogenesis response alleles substantially lie in the "dark matter." In this context it should be noted that the design of current GWASs has resulted in enrichment for genes active very early in tumor initiation, which thus confer susceptibility to both pre-cancerous (and pre-angiogenic) lesions and frank cancer (Varghese and Easton 2010). As outlined above, candidate gene studies have often found that angiogenesis gene polymorphisms exhibit stronger effects on tumor progression or metastasis than in tumor incidence. Thus, as GWASs move toward more refined comparisons, it is likely that angiogenesis genes will appear in greater numbers. Indeed, because cancer susceptibility results from the interplay of a large number of different processes, one means of identifying risk alleles is to use intermediate phenotypes that are affected by a smaller number of processes, thus limiting the diluting effect of other processes (e.g., apoptosis susceptibility). Second, the involvement in a wide variety of processes critical to life may limit the extent to which variation in angiogenesis-regulating genes is evolutionarily permitted. This, in turn, will limit the relative risk attributable to any given allele, and thus the detectability of that allele. Finally, current GWASs rely heavily on a tag SNP approach. Although current knowledge necessitates such an approach, it is likely to be less effective than a function SNP approach. It is thus to be anticipated that, as GWAS techniques are refined, angiogenesis-regulating genes will appear with greater frequency in the results of such studies.

\section{LOCI IDENTIFIED IN ANIMAL STUDIES}

Several experiments in rodents, designed to map tumor-related traits, have identified loci that affect angiogenic response (Table 2). For example, in the estrogen-induced pituitary tumor model, a locus on rat chromosome 5, Edpm5, affects tumor mass and vascularity and is associated with the switch to the angiogenic phenotype (Pandey et al. 2004). Similarly, decreased proliferative capacity and altered latency associated with altered angiogenesis have been observed in MMTV-PyMT mice with specific genotypes at any of three loci: Mmtg1, Mmtg2, and Mmtg3 (Le Voyer et al. 2001). In addition to altering growth or latency characteristics, differences in angiogenic responsiveness 
M.S. Rogers and R.J. D'Amato

Table 2. Rodent angiogenic response QTLs

\begin{tabular}{|c|c|c|c|c|}
\hline QTL & Location & Effect of paternal allele & Cross & Reference \\
\hline Edpm5 & Rat Chr 5M & $\begin{array}{l}\text { Resistance to estrogen- } \\
\text { induced pituitary } \\
\text { tumor angiogenesis }\end{array}$ & Fisher 344 x Brown Norway & Pandey et al. 2004 \\
\hline Skts 9 & Chr 16P & Skin tumor resistance & NIH/Ola x M. spretus & Nagase et al. 1999 \\
\hline Mmtg1 & Chr 4P & Increased tumor burden & $\begin{array}{l}\text { I/LnJ x } \\
\text { FVB/N-TgN(MMTV-PyVT })^{634 M u 1}\end{array}$ & Le Voyer et al. 2001 \\
\hline Mmtg2 & Chr 4M & Increased tumor burden & $\begin{array}{l}\text { I/LnJ x } \\
\text { FVB/N-TgN(MMTV-PyVT })^{634 M u 1}\end{array}$ & Le Voyer et al. 2001 \\
\hline Mmtg3 & Chr 7P & Decreased tumor burden & $\begin{array}{l}\text { I/LnJ x } \\
\text { FVB/N-TgN(MMTV-PyVT })^{634 M u l}\end{array}$ & Le Voyer et al. 2001 \\
\hline$T g f b k m 2$ & Chr 1D & $\begin{array}{c}\text { Normal yolk sac } \\
\text { angiogenesis }\end{array}$ & $\begin{array}{l}\text { C57BL/6 Tgfb } 1^{+/-} \mathrm{x} \\
129 \mathrm{~S} 2 / \mathrm{Sv} T g f b 1^{+/-}\end{array}$ & Tang et al. 2003 \\
\hline $\operatorname{Tgfbm} 1$ & Chr 5P & $\begin{array}{c}\text { Normal yolk sac } \\
\text { Angiogenesis }\end{array}$ & $\begin{array}{l}\text { C57BL/6 Tgfb1 } 1^{+/-} \mathrm{x} \\
\text { NIH/OlaHsd Tgfb1 }\end{array}$ & Tang et al. 2005 \\
\hline$T g f b m 3$ & Chr $12 \mathrm{P}$ & $\begin{array}{l}\text { Normal yolk sac } \\
\text { angiogenesis }\end{array}$ & $\begin{array}{l}\text { C57BL/6 Tgfb1 } 1^{+/-} \mathrm{x} \\
\text { NIH/OlaHsd Tgfb1 }\end{array}$ & Tang et al. 2005 \\
\hline$A n g V q 1$ & Chr 10M & $\begin{array}{l}\text { Increased VEGF-induced } \\
\text { angiogenesis }\end{array}$ & $\mathrm{C} 57 \mathrm{BL} / 6 \mathrm{~J} \times \mathrm{DBA} / 2 \mathrm{~J}$ & $\underset{\mathrm{a}}{\text { Rogers et al. 2003, }}$ \\
\hline AngVq2 & Chr 2P & $\begin{array}{l}\text { Decreased } \\
\text { VEGF-induced } \\
\text { angiogenesis }\end{array}$ & $\begin{array}{c}\mathrm{C} 57 \mathrm{BL} / 6 \mathrm{~J} \times \mathrm{DBA} / 2 \mathrm{~J} \\
\mathrm{C} 57 \mathrm{BL} / 6 \mathrm{~J} \times \mathrm{A} / \mathrm{J}\end{array}$ & $\begin{array}{l}\text { Rogers et al. 2003, } \\
\text { a }\end{array}$ \\
\hline$A n g V q 3$ & Chr 10P & $\begin{array}{l}\text { Decreased } \\
\text { VEGF-induced } \\
\text { angiogenesis }\end{array}$ & $\begin{array}{c}\mathrm{C} 57 \mathrm{BL} / 6 \mathrm{~J} \times \mathrm{DBA} / 2 \mathrm{~J} \\
\mathrm{C} 57 \mathrm{BL} / 6 \mathrm{~J} \times \mathrm{A} / \mathrm{J}\end{array}$ & $\begin{array}{l}\text { Rogers et al. 2003, } \\
\text { a }\end{array}$ \\
\hline AngVq4 & Chr 7M & $\begin{array}{l}\text { Decreased } \\
\text { VEGF-induced } \\
\text { angiogenesis }\end{array}$ & $\mathrm{C} 57 \mathrm{BL} / 6 \mathrm{~J} \times \mathrm{A} / \mathrm{J}$ & a \\
\hline AngVq5 & Chr Y & $\begin{array}{l}\text { Decreased } \\
\text { VEGF-induced } \\
\text { angiogenesis }\end{array}$ & $\begin{array}{l}\mathrm{C} 57 \mathrm{BL} / 6 \mathrm{~J} \times \mathrm{A} / \mathrm{J} \\
\mathrm{C} 57 \mathrm{BL} / 6 \mathrm{~J} \times \mathrm{SJL}\end{array}$ & a \\
\hline AngFq1 & Chr 4P & $\begin{array}{l}\text { Increased bFGF-induced } \\
\text { angiogenesis }\end{array}$ & $\mathrm{C} 57 \mathrm{BL} / 6 \mathrm{~J} \times \mathrm{DBA} / 2 \mathrm{~J}$ & Rogers et al. 2004 \\
\hline AngFq2 & Chr 13P & $\begin{array}{l}\text { Decreased bFGF-induced } \\
\text { angiogenesis }\end{array}$ & $\mathrm{C} 57 \mathrm{BL} / 6 \mathrm{~J} \times \mathrm{DBA} / 2 \mathrm{~J}$ & Rogers et al. 2004 \\
\hline AngFq3 & Chr 15M & $\begin{array}{l}\text { Increased bFGF-induced } \\
\text { angiogenesis }\end{array}$ & $\mathrm{C} 57 \mathrm{BL} / 6 \mathrm{~J} \times \mathrm{DBA} / 2 \mathrm{~J}$ & Rogers et al. 2004 \\
\hline AngFq4 & Chr 18D & $\begin{array}{l}\text { Increased bFGF-induced } \\
\text { angiogenesis }\end{array}$ & $\begin{array}{l}\mathrm{C} 57 \mathrm{BL} / 6 \mathrm{~J} \times \mathrm{DBA} / 2 \mathrm{~J} \\
\mathrm{C} 57 \mathrm{BL} / 6 \mathrm{~J} \times 129 \mathrm{P} 3 / \mathrm{J}\end{array}$ & Rogers et al. 2004 \\
\hline AngFq5 & Chr 7P & $\begin{array}{l}\text { Decreased bFGF-induced } \\
\text { angiogenesis }\end{array}$ & $\mathrm{C} 57 \mathrm{BL} / 6 \mathrm{~J} \times \mathrm{SJL} / \mathrm{J}$ & $\mathrm{b}$ \\
\hline AngFq6 & Chr 12P & $\begin{array}{l}\text { Increased bFGF-induced } \\
\text { angiogenesis }\end{array}$ & $\begin{array}{l}\mathrm{C} 57 \mathrm{BL} / 6 \mathrm{~J} \times 129 \mathrm{P} 3 / \mathrm{J} \\
\text { C57BL/6J x 129P1/ReJ }\end{array}$ & $\mathrm{b}$ \\
\hline AngFq7 & Chr 14M & $\begin{array}{l}\text { Decreased bFGF-induced } \\
\text { angiogenesis }\end{array}$ & $\mathrm{C} 57 \mathrm{BL} / 6 \mathrm{~J} \times 129 \mathrm{P} 3 / \mathrm{J}$ & $\mathrm{b}$ \\
\hline AngFq8 & Chr Y & $\begin{array}{l}\text { Decreased bFGF-induced } \\
\text { angiogenesis }\end{array}$ & $\begin{array}{l}\mathrm{C} 57 \mathrm{BL} / 6 \mathrm{~J} \times \mathrm{A} / \mathrm{J} \\
\mathrm{C} 57 \mathrm{BL} / 6 \mathrm{~J} \times \mathrm{SJL}\end{array}$ & $\mathrm{b}$ \\
\hline
\end{tabular}

Quantitative trait loci (QTLs) for differences in angiogenic responsiveness along with their peak chromosomal location (P, proximal third; M, middle third; D, distal third), effect of the paternal (strain listed second) allele, and cross(es) in which the trait segregates.

${ }^{a}$ MS Rogers, AE Birsner, and RJ D'Amato, unpubl.

${ }^{\mathrm{b}}$ MS Rogers, V Boyartchuk, AE Birsner, et al., unpubl. 
may alter tumor shape or eccentricity. This may result when in a given region of a growing tumor the fraction of angiogenic tumor cells drops below the threshold necessary to maintain angiogenesis (Udagawa et al. 2002). When this occurs, the tumor ceases to grow locally, resulting in alteration of tumor shape. Thus, several lung tumor shape-determining loci (Ltsd) may also be angiogenesis-response loci (Tripodis and Demant 2003).

We have used the mouse corneal micropocket assay (Rogers et al. 2007) to identify several quantitative trait loci (QTLs) that control response to bFGF and/or VEGF. Importantly, these studies contrast with knockout studies because the variation underlying the trait has survived the rigors of inbreeding and the breeding requirements of colony maintenance. As a result, it is likely to more closely model common human polymorphisms that are responsible for the bulk of human disease than would other approaches. We have found results of the corneal micropocket assay to be stable with regard to animal age and cage environment, with two studies showing that genetic differences explain more than 20 times the variance that is explained by environmental factors (Rogers et al. 2003, 2004).

We have used the BXD (C57BL/6J x DBA/ 2J) recombinant inbred strain cross to identify bFGF response loci. As a result, we identified loci on chromosome 4,13,15, and 18 which we named AngFq1-AngFq4 for angiogenesis in response to bFGF (Rogers et al. 2004). Each of these loci has been confirmed with a congenic animal from the genome-tagged mouse set (Iakoubova et al. 2001). In addition, earlier mapping studies using F2 crosses between 129P3/J, 129P1ReJ, or SJL/J and C57BL/6J identified four QTLs, one each on chromosomes 7, 12, 14, and Y (AngFq5-AngFq8). In the case of $A n g F q 5$, congenic animal generation combined with haplotype mapping identified the pink-eyed dilution mutation as a candidate that might explain the phenotype. This candidate was confirmed using the distinct $\mathrm{pJ}$ allele in the same gene. Thus, unexpectedly, pinkeyed dilution was identified as a gene that affects angiogenic responsiveness.
In the case of VEGF, mapping using the BXD strain set resulted in the identification of two QTLs, $A n g V q 1$ in the middle of chromosome 10 and $A n g V q 2$ in the proximal portion of chromosome 2, each of which has been confirmed with a GTM mouse (Rogers et al. 2003; Rogers and D'Amato 2006). Importantly, a comparison of angiogenic response to bFGF and VEGF in the BXD strain set demonstrated substantial correlation. This may be a result of the observation that a substantial fraction of bFGF response can be inhibited by a VEGF inhibitor, indicating that a portion of the bFGF response is mediated by VEGF. Subsequent work with the AXB and BXA strain sets as well as with chromosome substitution strains (Hill et al. 2006) has resulted in the identification of a second QTL on chromosome $10(A n g V q 3)$ as well as QTLs on chromosomes 7 (AngVq4) and Y (AngVq5). Subsequent mapping work has identified the albino mutation in tyrosinase as responsible for AngVq4 (MS Rogers, AE Birsner, and RJ D'Amato, unpubl.). Thus, in at least two cases, coat color loci can affect angiogenic response, indicating an overlap in the two pathways.

In addition to corneal angiogenesis, we have also extended this work to identify QTLs that control the neovascular area in a laser-induced mouse model of age-related macular degeneration (Nakai et al. 2009). In this case, because retinal pigmentation affects the amount of laser energy deposited, pigmentation-related alleles had to be controlled for. This mapping confirmed $A n g V q 1$ and $A n g F q 2$. It also resulted in the identification of two new QTLs, AngCNVq1 and AngCNVq2 on chromosomes 2 and 19, respectively.

In addition to angiogenesis response QTLs, other QTLs affect the vasculature in inbred mice. For example, the extent and remodeling of collateral arteries are genetically controlled traits that can affect the outcome of ischemic injury (Wang et al. 2010b). Intestinal lymphatic vasculature can be affected by a QTL on chromosome 3 that includes the VCAM1 gene (Jurisic et al. 2010), and both basal and induced corneal lymphatics differ among mouse strains (Nakao et al. 2010). These traits appear, 
M.S. Rogers and R.J. D'Amato

however, to be both mechanistically and genetically distinct from angiogenic responsiveness.

\section{CONCLUSIONS}

The study of the role of genetic variation in the angiogenic response is currently in its infancy. Nevertheless, it is now clear that polymorphisms in angiogenesis-regulating genes can affect a large number of phenotypes, including a wide variety related to disease processes in man. In none of these cases does an absence of association necessarily imply that the gene/protein in question is not involved in disease. Rather, it may simply mean that functional polymorphisms in the gene have not been identified or do not exist at sufficient frequency in the study populations. Importantly, odds ratios for disease susceptibility in angiogenesis-regulating genes tend to be low, with meta-analysis typically demonstrating odds ratios in the $1.1-1.3$ range. This is likely to be a result of purifying selection. Nevertheless, the large number of angiogenesis-regulating genes currently identified means that, even assuming no epistatic interaction among polymorphisms, the overall risk due to angiogenesis-regulating polymorphisms could be quite high. Epistatic interactions among members of interacting pathways may substantially increase risk. Indeed, the few studies that have looked at multiple angiogenesis-regulating polymorphisms have found odds ratios associated with three risk alleles to be in the six to seven range for susceptibility (a range that would be expected to have required approximately 15 risk alleles without epistatic interactions) and 20 for tumor aggressiveness (Gerger et al. 2007; Sfar et al. 2009). Given the pervasive epistasis found in other studies of complex traits (Shao et al. 2008), it is likely that the sum of angiogenic response alleles plays a major role in angiogenesis-dependent disease. Combined with the number of angiogenesisregulated diseases and traits, it is not surprising that polymorphisms in just one angiogenesis regulator are associated with human lifespan (Del Bo et al. 2008), and it is likely that the sum of angiogenesis-regulating variation plays a major role in determining the length and quality of life.

\section{REFERENCES}

Ahmetov II, Hakimullina AM, Popov DV, Lyubaeva EV, Missina SS, Vinogradova OL, Williams AG, Rogozkin VA. 2009. Association of the VEGFR2 gene His472Gln polymorphism with endurance-related phenotypes. Eur J Appl Physiol 107: 95-103.

An E, Sen S, Park SK, Gordish-Dressman H, Hathout Y. 2010. Identification of novel substrates for the serine protease HTRA1 in the human RPE secretome. Invest Ophthalmol Vis Sci 51: 3379-3386.

Anand-Apte B, Pepper MS, Voest E, Montesano R, Olsen B, Murphy G, Apte SS, Zetter B. 1997. Inhibition of angiogenesis by tissue inhibitor of metalloproteinase-3. Invest Ophthalmol Vis Sci 38: 817-823.

Andersson U, Schwartzbaum J, Wiklund F, Sjostrom S, Liu Y, Tsavachidis S, Ahlbom A, Auvinen A, Collatz-Laier H, Feychting M, et al. 2010. A comprehensive study of the association between the EGFR and ERBB2 genes and glioma risk. Acta Oncol 49: 767-775.

Awata T, Kurihara S, Takata N, Neda T, Iizuka H, Ohkubo T, Osaki M, Watanabe M, Nakashima Y, Inukai K, et al. 2005. Functional VEGF C-634G polymorphism is associated with development of diabetic macular edema and correlated with macular retinal thickness in type 2 diabetes. Biochem Biophys Res Commun 333: 679-685.

Ayala F, Corral J, Gonzalez-Conejero R, Sanchez I, Moraleda JM, Vicente V. 2003. Genetic polymorphisms of platelet adhesive molecules: Association with breast cancer risk and clinical presentation. Breast Cancer Res Treat 80: $145-154$.

Balan V, Nangia-Makker P, Schwartz AG, Jung YS, Tait L, Hogan V, Raz T, Wang Y, Yang ZQ, Wu GS, et al. 2008. Racial disparity in breast cancer and functional germ line mutation in galectin-3 (rs4644): A pilot study. Cancer Res 68: 10045-10050.

Beranek M, Kolar P, Tschoplova S, Kankova K, Vasku A 2008. Genetic variations and plasma levels of gelatinase A (matrix metalloproteinase-2) and gelatinase B (matrix metalloproteinase-9) in proliferative diabetic retinopathy. Mol Vis 14: 1114-1121.

Bhanoori M, Arvind Babu K, Pavankumar Reddy NG, Lakshmi Rao K, Zondervan K, Deenadayal M, Kennedy S, Shivaji S. 2005. The vascular endothelial growth factor (VEGF) $+405 \mathrm{G}>\mathrm{C} 5^{\prime}$-untranslated region polymorphism and increased risk of endometriosis in South Indian women: A case control study. Hum Reprod 20: 1844-1849.

Bojesen SE, Tybjaerg-Hansen A, Nordestgaard BG. 2003. Integrin $\beta_{3}$ Leu33Pro homozygosity and risk of cancer. J Natl Cancer Inst 95: 1150-1157.

Brooks JT, Elvidge GP, Glenny L, Gleadle JM, Liu C, Ragoussis J, Smith TG, Talbot NP, Winchester L, Maxwell PH, et al. 2009. Variations within oxygen-regulated gene expression in humans. J Appl Physiol 106: 212-220.

Cahan P, Li Y, Izumi M, Graubert TA. 2009. The impact of copy number variation on local gene expression in mouse hematopoietic stem and progenitor cells. Nat Genet 41: 430-437.

Chen Y, Cicciarelli J, Pravica V, Hutchinson IV. 2009. Longrange linkage on chromosome 6p of VEGF, FKBP5, HLA 
and TNF alleles associated with transplant rejection. $\mathrm{Mol}$ Immunol 47: 96-100.

Chen MH, Tzeng CH, Chen PM, Lin JK, Lin TC, Chen WS, Jiang JK, Wang HS, Wang WS. 2010a. VEGF -460T $\rightarrow$ C polymorphism and its association with VEGF expression and outcome to FOLFOX-4 treatment in patients with colorectal carcinoma. Pharmacogenomics J 11: 227-236.

Chen W, Stambolian D, Edwards AO, Branham KE, Othman M, Jakobsdottir J, Tosakulwong N, Pericak-Vance MA, Campochiaro PA, Klein ML, et al. 2010b. Genetic variants near TIMP3 and high-density lipoprotein-associated loci influence susceptibility to age-related macular degeneration. Proc Natl Acad Sci 107: 7401-7406.

Cho EK, Tchinda J, Freeman JL, Chung YJ, Cai WW, Lee C. 2006. Array-based comparative genomic hybridization and copy number variation in cancer research. Cytogenet Genome Res 115: 262-272.

Del Bo R, Scarlato M, Ghezzi S, Maestroni A, Sjolind L, Forsblom C, Wessman M, Groop PH, Comi GP, Bresolin N et al. 2006. VEGF gene variability and type 1 diabetes: Evidence for a protective role. Immunogenetics 58: 107-112.

Del Bo R, Ghezzi S, Scarlato M, Albani D, Galimberti D, Lucca U, Tettamanti M, Scarpini E, Forloni G, Bresolin N, et al. 2008. Role of VEGF gene variability in longevity: A lesson from the Italian population. Neurobiol Aging 29: 1917-1922.

Dewan A, Liu M, Hartman S, Zhang SS, Liu DT, Zhao C, Tam PO, Chan WM, Lam DS, Snyder M, et al. 2006. HTRA1 promoter polymorphism in wet age-related macular degeneration. Science 314: 989-992.

Easton DF, Pooley KA, Dunning AM, Pharoah PD, Thompson D, Ballinger DG, Struewing JP, Morrison J, Field H, Luben R, et al. 2007. Genome-wide association study identifies novel breast cancer susceptibility loci. Nature 447: 1087-1093.

Ellis SG, Chen MS, Jia G, Luke M, Cassano J, Lytle B. 2007. Relation of polymorphisms in five genes to long-term aortocoronary saphenous vein graft patency. Am J Cardiol 99: 1087-1089.

Etienne-Grimaldi MC, Formento P, Degeorges A, Pierga JY, Delva R, Pivot X, Dalenc F, Espie M, Veyret C, Formento JL, et al. 2010. Prospective analysis of the impact of VEGF-A gene polymorphisms on pharmacodynamics of bevacizumab-based therapy in metastatic breast cancer patients. Br J Clin Pharmacol 71: 921-928.

Fiotti N, Pedio M, Battaglia Parodi M, Altamura N, Uxa L, Guarnieri G, Giansante C, Ravalico G. 2005. MMP-9 microsatellite polymorphism and susceptibility to exudative form of age-related macular degeneration. Genet Med 7: 272-277.

Francis PJ, Hamon SC, Ott J, Weleber RG, Klein ML. 2009. Polymorphisms in C2, CFB and C3 are associated with progression to advanced age related macular degeneration associated with visual loss. J Med Genet 46: 300-307.

Fujita S, Masago K, Hatachi Y, Fukuhara A, Hata A, Kaji R, Kim YH, Mio T, Mishima M, Katakami N. 2010. Genetic polymorphisms in the endothelial nitric oxide synthase gene correlate with overall survival in advanced nonsmall-cell lung cancer patients treated with platinumbased doublet chemotherapy. BMC Med Genet 11: 167.
Funke S, Risch A, Nieters A, Hoffmeister M, Stegmaier C, Seiler CM, Brenner H, Chang-Claude J. 2009. Genetic polymorphisms in genes related to oxidative stress (GSTP1, GSTM1, GSTT1, CAT, MnSOD, MPO, eNOS) and survival of rectal cancer patients after radiotherapy. J Cancer Epidemiol 2009: 302047.

Galan A, Ferlin A, Caretti L, Buson G, Sato G, Frigo AC, Foresta C. 2010. Association of age-related macular degeneration with polymorphisms in vascular endothelial growth factor and its receptor. Ophthalmology 117: $1769-1774$.

Gao LB, Pan XM, Jia J, Liang WB, Rao L, Xue H, Zhu Y, Li SL, Lv ML, Deng W, et al. 2010. IL-8 -251A/T polymorphism is associated with decreased cancer risk among population-based studies: Evidence from a metaanalysis. Eur J Cancer 46: 1333-1343.

Garcia-Closas M, Malats N, Real FX, Yeager M, Welch R, Silverman D, Kogevinas M, Dosemeci M, Figueroa J, Chatterjee N, et al. 2007. Large-scale evaluation of candidate genes identifies associations between VEGF polymorphisms and bladder cancer risk. PLoS Genet 3: e29.

Gaudet MM, Kirchhoff T, Green T, Vijai J, Korn JM, Guiducci C, Segre AV, McGee K, McGuffog L, Kartsonaki C, et al. 2010. Common genetic variants and modification of penetrance of BRCA2-associated breast cancer. PLoS Genet 6: e1001183.

Gerger A, Langsenlehner U, Renner W, Weitzer W, Eder T, Yazdani-Biuki B, Hofmann G, Samonigg H, Krippl P. 2007. A multigenic approach to predict breast cancer risk. Breast Cancer Res Treat 104: 159-164.

Glueck CJ, Freiberg RA, Oghene J, Fontaine RN, Wang P. 2007. Association between the T-786C eNOS polymorphism and idiopathic osteonecrosis of the head of the femur. J Bone Joint Surg Am 89: 2460-2468.

Gordon MA, Gil J, Lu B, Zhang W, Yang D, Yun J, Schneider S, Groshen S, Iqbal S, Press OA, et al. 2006. Genomic profiling associated with recurrence in patients with rectal cancer treated with chemoradiation. Pharmacogenomics 7: 67-88.

Haas P, Aggermann T, Steindl K, Krugluger W, Puhringer H, Oberkanins C, Frantal S, Binder S. 2009. Genetic cardiovascular risk factors and age-related macular degeneration. Acta Ophthalmol 89: 335-338.

Hanaoka M, Droma Y, Ota M, Ito M, Katsuyama Y, Kubo K. 2009. Polymorphisms of human vascular endothelia growth factor gene in high-altitude pulmonary oedema susceptible subjects. Respirology 14: 46-52.

Hansen TF, Sorensen FB, Spindler KL, Olsen DA, Andersen RF, Lindebjerg J, Brandslund I, Jakobsen A. 2010. Microvessel density and the association with single nucleotide polymorphisms of the vascular endothelial growth factor receptor 2 in patients with colorectal cancer. Virchows Arch 456: 251-260.

Hao Y, Montiel R, Huang Y. 2010. Endothelial nitric oxide synthase (eNOS) $894 \mathrm{G}>\mathrm{T}$ polymorphism is associated with breast cancer risk: A meta-analysis. Breast Cancer Res Treat 124: 809-813.

Heist RS, Zhai R, Liu G, Zhou W, Lin X, Su L, Asomaning K, Lynch TJ, Wain JC, Christiani DC. 2008. VEGF polymorphisms and survival in early-stage non-small-cell lung cancer. J Clin Oncol 26: 856-862. 
M.S. Rogers and R.J. D'Amato

Hildebrandt MA, Komaki R, Liao Z, Gu J, Chang JY, Ye Y, Lu C, Stewart DJ, Minna JD, Roth JA, et al. 2010. Genetic variants in inflammation-related genes are associated with radiation-induced toxicity following treatment for non-small cell lung cancer. PLoS One 5: e12402.

Hill AE, Lander ES, Nadeau JH. 2006. Chromosome substitution strains: A new way to study genetically complex traits. Methods Mol Med 128: 153-172.

Hlatky MA, Quertermous T, Boothroyd DB, Priest JR, Glassford AJ, Myers RM, Fortmann SP, Iribarren C, Tabor HK, Assimes TL, et al. 2007. Polymorphisms in hypoxia inducible factor 1 and the initial clinical presentation of coronary disease. Am Heart J 154: 1035-1042.

Hong JM, Kim TH, Chae SC, Koo KH, Lee YJ, Park EK, Choi JY, Ryoo HM, Kim SY. 2007. Association study of hypoxia inducible factor $1 \alpha(\mathrm{HIF} 1 \alpha)$ with osteonecrosis of femoral head in a Korean population. Osteoarthritis Cartilage 15: 688-694.

Hong JM, Kim TH, Kim HJ, Park EK, Yang EK, Kim SY 2010. Genetic association of angiogenesis- and hypoxia-related gene polymorphisms with osteonecrosis of the femoral head. Exp Mol Med 42: 376-385.

Howell WM, Bateman AC, Turner SJ, Collins A, Theaker JM. 2002. Influence of vascular endothelial growth factor single nucleotide polymorphisms on tumour development in cutaneous malignant melanoma. Genes Immun 3: $229-232$.

Hull J, Thomson A, Kwiatkowski D. 2000. Association of respiratory syncytial virus bronchiolitis with the interleukin 8 gene region in UK families. Thorax 55: 1023-1027.

Hunter DJ, Kraft P, Jacobs KB, Cox DG, Yeager M, Hankinson SE, Wacholder S, Wang Z, Welch R, Hutchinson A, et al. 2007. A genome-wide association study identifies alleles in FGFR2 associated with risk of sporadic postmenopausal breast cancer. Nat Genet 39: 870-874.

Iakoubova OA, Olsson CL, Dains KM, Ross DA, Andalibi A, Lau K, Choi J, Kalcheva I, Cunanan M, Louie J, et al. 2001. Genome-tagged mice (GTM): Two sets of genomewide congenic strains. Genomics 74: 89-104.

Ishimitsu T, Hosoya K, Tsukada K, Minami J, Futoh Y, Ono H, Ohrui M, Hino J, Kangawa K, Matsuoka H. 2001. Microsatellite DNA polymorphism of human adrenomedullin gene in normotensive subjects and patients with essential hypertension. Hypertension 38: 9-12.

Italiano JE Jr, Richardson JL, Patel-Hett S, Battinelli E, Zaslavsky A, Short S, Ryeom S, Folkman J, Klement GL. 2008. Angiogenesis is regulated by a novel mechanism: Pro- and antiangiogenic proteins are organized into separate platelet alpha granules and differentially released. Blood 111: 1227-1233.

Jacobs EJ, Hsing AW, Bain EB, Stevens VL, Wang Y, Chen J, Chanock SJ, Zheng SL, Xu J, Thun MJ, et al. 2008. Polymorphisms in angiogenesis-related genes and prostate cancer. Cancer Epidemiol Biomarkers Prev 17: 972-977.

Jain L, Sissung TM, Danesi R, Kohn EC, Dahut WL, Kummar S, Venzon D, Liewehr D, English BC, Baum CE, et al. 2010. Hypertension and hand-foot skin reactions related to VEGFR2 genotype and improved clinical outcome following bevacizumab and sorafenib. J Exp Clin Cancer Res 29: 95.

Jakubowska A, Gronwald J, Menkiszak J, Gorski B, Huzarski T, Byrski T, Edler L, Lubinski J, Scott RJ, Hamann U. 2008.
The VEGF_936_C $>$ T 3 'UTR polymorphism reduces BRCA1-associated breast cancer risk in Polish women. Cancer Lett 262: 71-76.

Jurisic G, Sundberg JP, Bleich A, Leiter EH, Broman KW, Buechler G, Alley L, Vestweber D, Detmar M. 2010. Quantitative lymphatic vessel trait analysis suggests Vcaml as candidate modifier gene of inflammatory bowel disease. Genes Immun 11: 219-231.

Kariyazono H, Ohno T, Khajoee V, Ihara K, Kusuhara K, Kinukawa N, Mizuno Y, Hara T. 2004. Association of vascular endothelial growth factor (VEGF) and VEGF receptor gene polymorphisms with coronary artery lesions of Kawasaki disease. Pediatr Res 56: 953-959.

Kim H, Ku SY, Kim SH, Lee GH, Choi YM, Kim JM, Lee TH, Moon SY. 2009a. Endothelial nitric oxide synthase gene Glu298Asp polymorphism is associated with advanced stage endometriosis. Hum Reprod 24: 2656-2659.

Kim JJ, Vaziri SA, Elson P, Rini BI, Ganapathi MK, Ganapathi R. 2009b. VEGF single nucleotide polymorphisms (SNPs) and correlation to sunitinib-induced hypertension (HTN) in metastatic renal cell carcinoma (mRCC) patients (pts). J Clin Oncol 27, suppl: abstr 5005.

Kim DH, Xu W, Kamel-Reid S, Liu X, Jung CW, Kim S, Lipton JH. 2010. Clinical relevance of vascular endothelial growth factor (VEGFA) and VEGF receptor (VEGFR2) gene polymorphism on the treatment outcome following imatinib therapy. Ann Oncol 21: 1179-1188.

Klagsbrun M, Shing Y. 1985. Heparin affinity of anionic and cationic capillary endothelial cell growth factors: Analysis of hypothalamus-derived growth factors and fibroblast growth factors. Proc Natl Acad Sci 82: 805-809.

Kloeckener-Gruissem B, Barthelmes D, Labs S, Schindler C, Kurz-Levin M, Michels S, Fleischhauer J, Berger W, Sutter F, Menghini M. 2011. Genetic association with response to intravitreal ranibizumab (Lucentis(R)) in neovascular AMD patients. Invest Ophthalmol Vis Sci 52: 4694-4702.

Kottgen A, Pattaro C, Boger CA, Fuchsberger C, Olden M, Glazer NL, Parsa A, Gao X, Yang Q, Smith AV, et al. 2010. New loci associated with kidney function and chronic kidney disease. Nat Genet 42: 376-384.

Krajinovic M, Robaey P, Chiasson S, Lemieux-Blanchard E, Rouillard M, Primeau M, Bournissen FG, Moghrabi A. 2005. Polymorphisms of genes controlling homocysteine levels and IQ score following the treatment for childhood ALL. Pharmacogenomics 6: 293-302.

Kuptsova N, Chang-Claude J, Kropp S, Helmbold I, Schmezer P, von Fournier D, Haase W, Sautter-Bihl ML, Wenz F, Onel K, et al. 2008. Genetic predictors of longterm toxicities after radiation therapy for breast cancer. Int J Cancer 122: 1333-1339.

Lamblin N, Cuilleret FJ, Helbecque N, Dallongeville J, Lablanche JM, Amouyel P, Bauters C, Van Belle E. 2005. A common variant of endothelial nitric oxide synthase (Glu298Asp) is associated with collateral development in patients with chronic coronary occlusions. BMC Cardiovasc Disord 5: 27.

Langsenlehner U, Renner W, Yazdani-Biuki B, Eder T, Wascher TC, Paulweber B, Clar H, Hofmann G, Samonigg H, Krippl P. 2006. Integrin alpha-2 and beta-3 gene polymorphisms and breast cancer risk. Breast Cancer Res Treat 97: 67-72. 
Le Voyer T, Rouse J, Lu Z, Lifsted T, Williams M, Hunter KW. 2001. Three loci modify growth of a transgene-induced mammary tumor: Suppression of proliferation associated with decreased microvessel density. Genomics 74: 253-261.

Lee WP, Tai DI, Lan KH, Li AF, Hsu HC, Lin EJ, Lin YP, Sheu ML, Li CP, Chang FY, et al. 2005. The -251T allele of the interleukin-8 promoter is associated with increased risk of gastric carcinoma featuring diffuse-type histopathology in Chinese population. Clin Cancer Res 11: 6431-6441.

Lee KM, Kang D, Park SK, Berndt SI, Reding D, Chatterjee N, Chanock S, Huang WY, Hayes RB. 2009a. Nitric oxide synthase gene polymorphisms and prostate cancer risk. Carcinogenesis 30: 621-625.

Lee SK, Kim MH, Cheong JY, Cho SW, Yang SJ, Kwack K. 2009b. Integrin alpha V polymorphisms and haplotypes in a Korean population are associated with susceptibility to chronic hepatitis and hepatocellular carcinoma. Liver Int 29: 187-195.

Li A, Dubey S, Varney ML, Dave BJ, Singh RK. 2003. IL-8 directly enhanced endothelial cell survival, proliferation, and matrix metalloproteinases production and regulated angiogenesis. J Immunol 170: 3369-3376.

Li K, Zhang Y, Dan Z, Wang Y, Ren ZC. 2009a. Association of the hypoxia inducible factor- $1 \alpha$ gene polymorphisms with gastric cancer in Tibetans. Biochem Genet 47: 625-634.

Li Y, Ambrosone CB, McCullough MJ, Ahn J, Stevens VL, Thun MJ, Hong CC. 2009b. Oxidative stress-related genotypes, fruit and vegetable consumption and breast cancer risk. Carcinogenesis 30: 777-784.

Li J, Humphreys K, Heikkinen T, Aittomaki K, Blomqvist C, Pharoah PD, Dunning AM, Ahmed S, Hooning MJ, Martens JW, et al. 2011. A combined analysis of genomewide association studies in breast cancer. Breast Cancer Res Treat 126: 717-727.

Lurje G, Zhang W, Schultheis AM, Yang D, Groshen S, Hendifar AE, Husain H, Gordon MA, Nagashima F, Chang HM, et al. 2008. Polymorphisms in VEGF and IL-8 predict tumor recurrence in stage III colon cancer. Ann Oncol 19: 1734-1741.

Lurje G, Husain H, Power DG, Yang D, Groshen S, Pohl A, Zhang W, Ning Y, Manegold PC, El-Khoueiry A, et al. 2010a. Genetic variations in angiogenesis pathway genes associated with clinical outcome in localized gastric adenocarcinoma. Ann Oncol 21: 78-86.

Lurje G, Leers JM, Pohl A, Oezcelik A, Zhang W, Ayazi S, Winder T, Ning Y, Yang D, Klipfel NE, et al. 2010b. Genetic variations in angiogenesis pathway genes predict tumor recurrence in localized adenocarcinoma of the esophagus. Ann Surg 251: 857-864.

Ma L, Perini R, McKnight W, Dicay M, Klein A, Hollenberg MD, Wallace JL. 2005. Proteinase-activated receptors 1 and 4 counter-regulate endostatin and VEGF release from human platelets. Proc Natl Acad Sci 102: 216-220.

Mandal K, Drury JA, Clark DI. 2007. An unusual case of retinopathy of prematurity. J Perinatol 27: 315-316.

Manolio TA, Collins FS, Cox NJ, Goldstein DB, Hindorff LA, Hunter DJ, McCarthy MI, Ramos EM, Cardon LR, Chakravarti A, et al. 2009. Finding the missing heritability of complex diseases. Nature 461: 747-753.
Marangoni K, Araujo TG, Neves AF, Goulart LR. 2008. The $-786 \mathrm{~T}>\mathrm{C}$ promoter polymorphism of the NOS3 gene is associated with prostate cancer progression. BMC Cancer 8: 273 .

Martinez A. 2006. A new family of angiogenic factors. Cancer Lett 236: 157-163.

McKay GJ, Silvestri G, Orr N, Chakravarthy U, Hughes AE. 2009. VEGF and age-related macular degeneration. Ophthalmology 116: e1221-1223.

Meyer KB, Maia AT, O’Reilly M, Teschendorff AE, Chin SF, Caldas C, Ponder BA. 2008. Allele-specific up-regulation of FGFR2 increases susceptibility to breast cancer. PLoS Biol 6: e108.

Nagase H, Mao JH, Balmain A. 1999. A subset of skin tumor modifier loci determines survival time of tumor-bearing mice. Proc Natl Acad Sci 96: 15032-15037.

Nakai K, Rogers MS, Baba T, Funakoshi T, Birsner AE, Luyindula DS, D'Amato RJ. 2009. Genetic loci that control the size of laser-induced choroidal neovascularization. FASEB J 23: 2235-2243.

Nakao S, Maruyama K, Zandi S, Melhorn MI, Taher M, Noda K, Nusayr E, Doetschman T, Hafezi-Moghadam A. 2010. Lymphangiogenesis and angiogenesis: Concurrence and/or dependence? Studies in inbred mouse strains. FASEB J 24: 504-513.

Nangia-Makker P, Wang Y, Raz T, Tait L, Balan V, Hogan V, Raz A. 2010. Cleavage of galectin-3 by matrix metalloproteases induces angiogenesis in breast cancer. Int $\mathrm{J}$ Cancer 127: $2530-2541$.

O'Reilly MS, Holmgren L, Shing Y, Chen C, Rosenthal RA, Moses M, Lane WS, Cao Y, Sage EH, Folkman J. 1994. Angiostatin: A novel angiogenesis inhibitor that mediates the suppression of metastases by a Lewis lung carcinoma. Cell 79: 315-328.

Oosthuyse B, Moons L, Storkebaum E, Beck H, Nuyens D, Brusselmans K, Van Dorpe J, Hellings P, Gorselink M, Heymans S, et al. 2001. Deletion of the hypoxia-response element in the vascular endothelial growth factor promoter causes motor neuron degeneration. Nat Genet 28: $131-138$.

Pabst S, Karpushova A, Diaz-Lacava A, Herms S, Walier M, Zimmer S, Cichon S, Nickenig G, Nothen MM, Wienker TF, et al. 2010. VEGF gene haplotypes are associated with sarcoidosis. Chest 137: 156-163.

Pander J, Wessels JA, Gelderblom H, van der Straaten T, Punt CJ, Guchelaar HJ. 2010. Pharmacogenetic interaction analysis for the efficacy of systemic treatment in metastatic colorectal cancer. Ann Oncol 22: 1147-1153.

Pandey J, Bannout A, Wendell DL. 2004. The Edpm5 locus prevents the "angiogenic switch" in an estrogen-induced rat pituitary tumor. Carcinogenesis 25: 1829-1838.

Pantsulaia I, Trofimov S, Kobyliansky E, Livshits G. 2004. Heritability of circulating growth factors involved in the angiogenesis in healthy human population. Cytokine 27: $152-158$.

Park HW, Lee JE, Shin ES, Lee JY, Bahn JW, Oh HB, Oh SY, Cho SH, Moon HB, Min KU, et al. 2006. Association between genetic variations of vascular endothelial growth factor receptor 2 and atopy in the Korean population. $J$ Allergy Clin Immunol 117: 774-779. 
M.S. Rogers and R.J. D'Amato

Park HW, Shin ES, Lee JE, Kwon HS, Chun E, Kim SS, Chang YS, Kim YK, Min KU, Kim YY, et al. 2007. Multilocus analysis of atopy in Korean children using multifactordimensionality reduction. Thorax 62: 265-269.

Qi JH, Ebrahem Q, Moore N, Murphy G, Claesson-Welsh L, Bond M, Baker A, Anand-Apte B. 2003. A novel function for tissue inhibitor of metalloproteinases-3 (TIMP3): Inhibition of angiogenesis by blockage of VEGF binding to VEGF receptor-2. Nat Med 9: 407-415.

Renner W, Kotschan S, Hoffmann C, Obermayer-Pietsch B, Pilger E. 2000. A common 936 C/T mutation in the gene for vascular endothelial growth factor is associated with vascular endothelial growth factor plasma levels. J Vasc Res 37: 443-448.

Resar JR, Roguin A, Voner J, Nasir K, Hennebry TA, Miller JM, Ingersoll R, Kasch LM, Semenza GL. 2005. Hypoxia-inducible factor 1 alpha polymorphism and coronary collaterals in patients with ischemic heart disease. Chest 128: 787-791.

Rogers MS, Birsner AE, D'Amato RJ. 2007. The mouse cornea micropocket angiogenesis assay. Nat Protoc 2: 2545-2550.

Rogers MS, D'Amato RJ. 2006. The effect of genetic diversity on angiogenesis. Exp Cell Res 312: 561-574.

Rogers MS, Rohan RM, Birsner AE, D’Amato RJ. 2003. Genetic loci that control vascular endothelial growth factor-induced angiogenesis. FASEB J 17: 2112-2114.

Rogers MS, Rohan RM, Birsner AE, D’Amato RJ. 2004. Genetic loci that control the angiogenic response to basic fibroblast growth factor. FASEB J 18: 1050-1059.

Rusai K, Vannay A, Szebeni B, Borgulya G, Fekete A, Vasarhelyi B, Tulassay T, Szabo AJ. 2008. Endothelial nitric oxide synthase gene T-786C and 27-bp repeat gene polymorphisms in retinopathy of prematurity. Mol Vis 14: 286-290.

Scartozzi M, Loretelli C, Bearzi I, Mandolesi A, Galizia E, Onofri A, Pistelli M, Bittoni A, Berardi R, Cascinu S. 2010. Allele polymorphisms of tumor integrins correlate with peritoneal carcinosis capability of gastric cancer cells in radically resected patients. Ann Oncol 22: 897-902.

Schadt EE, Monks SA, Drake TA, Lusis AJ, Che N, Colinayo V, Ruff TG, Milligan SB, Lamb JR, Cavet G, et al. 2003. Genetics of gene expression surveyed in maize, mouse and man. Nature 422: 297-302.

Schneider BP, Wang M, Radovich M, Sledge GW, Badve S, Thor A, Flockhart DA, Hancock B, Davidson N, Gralow J, et al. 2008. Association of vascular endothelial growth factor and vascular endothelial growth factor receptor-2 genetic polymorphisms with outcome in a trial of paclitaxel compared with paclitaxel plus bevacizumab in advanced breast cancer: ECOG 2100. J Clin Oncol 26: 4672-4678.

Schultheis AM, Lurje G, Rhodes KE, Zhang W, Yang D, Garcia AA, Morgan R, Gandara D, Scudder S, Oza A, et al. 2008. Polymorphisms and clinical outcome in recurrent ovarian cancer treated with cyclophosphamide and bevacizumab. Clin Cancer Res 14: 7554-7563.

Sfar S, Saad H, Mosbah F, Chouchane L. 2009. Combined effects of the angiogenic genes polymorphisms on prostate cancer susceptibility and aggressiveness. Mol Biol Rep 36: 37-45.
Sfar S, Saad H, Mosbah F, Chouchane L. 2010. Synergistic effect and VEGF/HSP70-hom haplotype analysis: Relationship to prostate cancer risk and clinical outcome. Hum Immunol 71: 377-382.

Shao H, Burrage LC, Sinasac DS, Hill AE, Ernest SR, O'Brien W, Courtland HW, Jepsen KJ, Kirby A, Kulbokas EJ, et al. 2008. Genetic architecture of complex traits: Large phenotypic effects and pervasive epistasis. Proc Natl Acad Sci 105: 19910-19914.

Shing Y, Folkman J, Sullivan R, Butterfield C, Murray J, Klagsbrun M. 1984. Heparin affinity: Purification of a tumor-derived capillary endothelial cell growth factor. Science 223: 1296-1299.

Simonson TS, Yang Y, HuffCD, Yun H, Qin G, Witherspoon DJ, Bai Z, Lorenzo FR, Xing J, Jorde LB, et al. 2010. Genetic evidence for high-altitude adaptation in Tibet. Science 329: 72-75.

Snoussi K, Mahfoudh W, Bouaouina N, Fekih M, Khairi H, Helal AN, Chouchane L. 2010. Combined effects of IL-8 and CXCR2 gene polymorphisms on breast cancer susceptibility and aggressiveness. BMC Cancer 10: 283.

Stevens A, Soden J, Brenchley PE, Ralph S, Ray DW. 2003. Haplotype analysis of the polymorphic human vascular endothelial growth factor gene promoter. Cancer Res 63: 812-816.

Stranger BE, Nica AC, Forrest MS, Dimas A, Bird CP, Beazley C, Ingle CE, Dunning M, Flicek P, Koller D, et al. 2007. Population genomics of human gene expression. Nat Genet 39: 1217-1224.

Su MT, Lin SH, Lee IW, Chen YC, Kuo PL. 2011. Association of polymorphisms/haplotypes of the genes encoding vascular endothelial growth factor and its KDR receptor with recurrent pregnancy loss. Hum Reprod 26: 758-764.

Tang Y, McKinnon ML, Leong LM, Rusholme SA, Wang S, Akhurst RJ. 2003. Genetic modifiers interact with maternal determinants in vascular development of Tgfb1 ${ }^{-/-}$mice. Hum Mol Genet 12: 1579-1589.

Tang Y, Lee KS, Yang H, Logan DW, Wang S, McKinnon ML, Holt LJ, Condie A, Luu MT, Akhurst RJ. 2005. Epistatic interactions between modifier genes confer strainspecific redundancy for Tgfb1 in developmental angiogenesis. Genomics 85: 60-70.

Tanimoto K, Yoshiga K, Eguchi H, Kaneyasu M, Ukon K, Kumazaki T, Oue N, Yasui W, Imai K, Nakachi K, et al. 2003. Hypoxia-inducible factor-lalpha polymorphisms associated with enhanced transactivation capacity, implying clinical significance. Carcinogenesis 24: 17791783.

Thomas G, Jacobs KB, Kraft P, Yeager M, Wacholder S, Cox DG, Hankinson SE, Hutchinson A, Wang Z, Yu K, et al. 2009. A multistage genome-wide association study in breast cancer identifies two new risk alleles at 1 p11.2 and 14q24.1 (RAD51L1). Nat Genet 41: 579-584.

Tripodis N, Demant P. 2003. Genetic analysis of threedimensional shape of mouse lung tumors reveals eight lung tumor shape-determining (Ltsd) loci that are associated with tumor heterogeneity and symmetry. Cancer Res 63: 125-131.

Turnbull C, Ahmed S, Morrison J, Pernet D, Renwick A, Maranian M, Seal S, Ghoussaini M, Hines S, Healey CS, et al. 2010. Genome-wide association study identifies 
five new breast cancer susceptibility loci. Nat Genet 42: 504-507.

Udagawa T, Fernandez A, Achilles EG, Folkman J, D’Amato RJ. 2002. Persistence of microscopic human cancers in mice: Alterations in the angiogenic balance accompanies loss of tumor dormancy. FASEB J 16: 1361-1370.

VanCleave TT, Moore JH, Benford ML, Brock GN, Kalbfleisch T, Baumgartner RN, Lillard JW Jr, Kittles RA, Kidd LC. 2010. Interaction among variant vascular endothelial growth factor (VEGF) and its receptor in relation to prostate cancer risk. Prostate 70: 341-352.

Varghese JS, Easton DF. 2010. Genome-wide association studies in common cancers-What have we learnt? Curr Opin Genet Dev 20: 201-209.

Vasku V, Vasku A, Tschoplova S, Izakovicova Holla L, Semradova V, Vacha J. 2002. Genotype association of $\mathrm{C}(-735) \mathrm{T}$ polymorphism in matrix metalloproteinase 2 gene with $\mathrm{G}(8002)$ A endothelin 1 gene with plaque psoriasis. Dermatology 204: 262-265.

Wang XL, Sim AS, Wang MX, Murrell GA, Trudinger B, Wang J. 2000. Genotype dependent and cigarette specific effects on endothelial nitric oxide synthase gene expression and enzyme activity. FEBS Lett 471: 45-50.

Wang Y, Zheng Y, Zhang W, Yu H, Lou K, Zhang Y, Qin Q, Zhao B, Yang Y, Hui R. 2007. Polymorphisms of KDR gene are associated with coronary heart disease. $J \mathrm{Am}$ Coll Cardiol 50: 760-767.

Wang LD, Zhou FY, Li XM, Sun LD, Song X, Jin Y, Li JM, Kong GQ, Qi H, Cui J, et al. 2010a. Genome-wide association study of esophageal squamous cell carcinoma in Chinese subjects identifies susceptibility loci at PLCE1 and C20orf54. Nat Genet 42: 759-763.

Wang S, Zhang H, Dai X, Sealock R, Faber JE. 2010b. Genetic architecture underlying variation in extent and remodeling of the collateral circulation. Circ Res 107: $558-568$.

Wang-Gohrke S, Chang-Claude J. 2004. Integrin beta3 Leu33Pro polymorphism and breast cancer risk: A population-based case-control study in Germany. Breast Cancer Res Treat 88: 231-237.
Common Polymorphisms in Angiogenesis

Weber BH, Vogt G, Pruett RC, Stohr H, Felbor U. 1994. Mutations in the tissue inhibitor of metalloproteinases-3 (TIMP3) in patients with Sorsby's fundus dystrophy. Nat Genet 8: 352-356.

Wipff J, Dieude P, Avouac J, Tiev K, Hachulla E, Granel B, Diot E, Sibilia J, Mouthon L, Meyer O, et al. 2009. Association of hypoxia-inducible factor 1A (HIF1A) gene polymorphisms with systemic sclerosis in a French European Caucasian population. Scand J Rheumatol 38: 291-294.

Yanamandra K, Napper D, Pramanik A, Bocchini JA Jr, Dhanireddy R. 2010. Endothelial nitric oxide synthase genotypes in the etiology of retinopathy of prematurity in premature infants. Ophthalmic Genet 31: 173-177.

Yang Z, Tong Z, Chen Y, Zeng J, Lu F, Sun X, Zhao C, Wang K, Davey L, Chen H, et al. 2010. Genetic and functional dissection of HTRA1 and LOC387715 in age-related macular degeneration. PLoS Genet 6: e1000836.

Zablotna M, Sobjanek M, Glen J, Niedoszytko M, Wilkowska A, Roszkiewicz J, Nedoszytko B. 2010. Association between the $-1154 \mathrm{G} / \mathrm{A}$ promoter polymorphism of the vascular endothelial growth factor gene and atopic dermatitis. J Eur Acad Dermatol Venereol 24: 91-92.

Zhang W, Sun K, Zhen Y, Wang D, Wang Y, Chen J, Xu J, Hu FB, Hui R. 2009. VEGF receptor-2 variants are associated with susceptibility to stroke and recurrence. Stroke 40: 2720-2726.

Zhao T, Lv J, Zhao J, Nzekebaloudou M. 2009. Hypoxiainducible factor-1alpha gene polymorphisms and cancer risk: A meta-analysis. J Exp Clin Cancer Res 28: 159.

Zheng ZL, Hwang YH, Kim SK, Kim S, Son MJ, Ro H, Sung SA, Lee HH, Chung WK, Joo KW, et al. 2009. Genetic polymorphisms of hypoxia-inducible factor- $1 \alpha$ and cardiovascular disease in hemodialysis patients. Nephron Clin Pract 113: C104-C111.

Zintzaras E, Grammatikou M, Kitsios GD, Doxani C, Zdoukopoulos N, Papandreou C, Patrikidou A. 2010. Polymorphisms of the endothelial nitric oxide synthase gene in breast cancer: A genetic association study and meta-analysis. J Hum Genet 55: 743-748. 


\section{$\&_{\mathrm{CSH}}^{\infty} \&$ Cold Spring Harbor

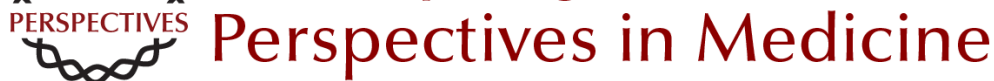

\section{Common Polymorphisms in Angiogenesis}

Michael S. Rogers and Robert J. D'Amato

Cold Spring Harb Perspect Med 2012; doi: 10.1101/cshperspect.a006510 originally published online September 28, 2011

\section{Subject Collection Angiogenesis}

Extracellular Matrix Regulation of Vascular Morphogenesis, Maturation, and Stabilization George E. Davis and Scott S. Kemp

Endothelial Cell-Pericyte Interactions in the Pathogenesis of Cerebral Cavernous Malformations (CCMs) Wang Min and Jenny Huanjiao Zhou

Lymphatic Clearance and Pump Function Jerome W. Breslin

Platelets and (Lymph)angiogenesis Harvey G. Roweth and Elisabeth M. Battinelli

Modeling Brain Vasculature Immune Interactions In Vitro Ruth Lyck, Hideaki Nishihara, Sidar Aydin, et al.

Human Endothelial Colony-Forming Cells Juan M. Melero-Martin

\section{The Beauty and Complexity of Blood Vessel} Patterning

Victoria L. Bautch and Yoh-suke Mukouyama

Endothelialitis, Microischemia, and

Intussusceptive Angiogenesis in COVID-19 Steven J. Mentzer, Maximilian Ackermann and Danny Jonigk
Regulation of the Blood-Brain Barrier in Health and Disease Cara C. Rada, Kanako Yuki, Jie Ding, et al.

Targeting Angiogenesis via Resolution of Inflammation

Abigail G. Kelly and Dipak Panigrahy

Notch Signaling in the Vasculature: Angiogenesis and Angiocrine Functions

Sana S. Hasan and Andreas Fischer

Signal Transduction and Gene Regulation in the Endothelium

Michel V. Levesque and Timothy Hla

Buttons and Zippers: Endothelial Junctions in

Lymphatic Vessels

Peter Baluk and Donald M. McDonald

Endothelial Cell Fate Determination: A Top Notch Job in Vascular Decision-Making

L.A. Naiche, Stephanie R. Villa and Jan K. Kitajewski

Leukocyte Trafficking in Lymphatic Vessels Aline Bauer, Hazal Tatliadim and Cornelia Halin

Lymphatic Tissue and Organ Engineering for In Vitro Modeling and In Vivo Regeneration Anna M. Kolarzyk, Gigi Wong and Esak Lee

For additional articles in this collection, see http://perspectivesinmedicine.cshlp.org/cgi/collection/ 